\title{
Does Business Confidence Influence Tax Compliance?
}

\author{
Țibulcă Ioana Laura \\ Bucharest University of Economic Studies, Romania
}

\begin{abstract}
In recent years one of the main topics of debate for tax authorities in the European Union has been tax compliance and, more specifically, changing tax legislation to increase tax compliance throughout the EU. The current study aims to establish the relationship between business confidence and tax compliance in order to decide if increasing business confidence would be an efficient way of increasing tax compliance level. Business confidence indicators are provided by Eurostat for four main sectors of the economy: the industrial sector, the construction sector, the retail sector and the services sector. Each of these indicators is determined based on the view business owners and managers in that particular sector have of how well their business is doing currently and how they expect things to evolve in the future. Tax compliance is determined using the VAT gap which is calculated as a percentage of VAT total tax liability according to tax law (data provided by Study and Reports on the VAT Gap in the EU-28 Member States: 2018 Final Report). Granger causality tests are used to establish if each business confidence indicator can be used to predict tax compliance levels. The results are sector-specific, and they are analyzed accordingly.
\end{abstract}

Keywords: construction confidence; industrial confidence; retail confidence; services confidence; taxation 